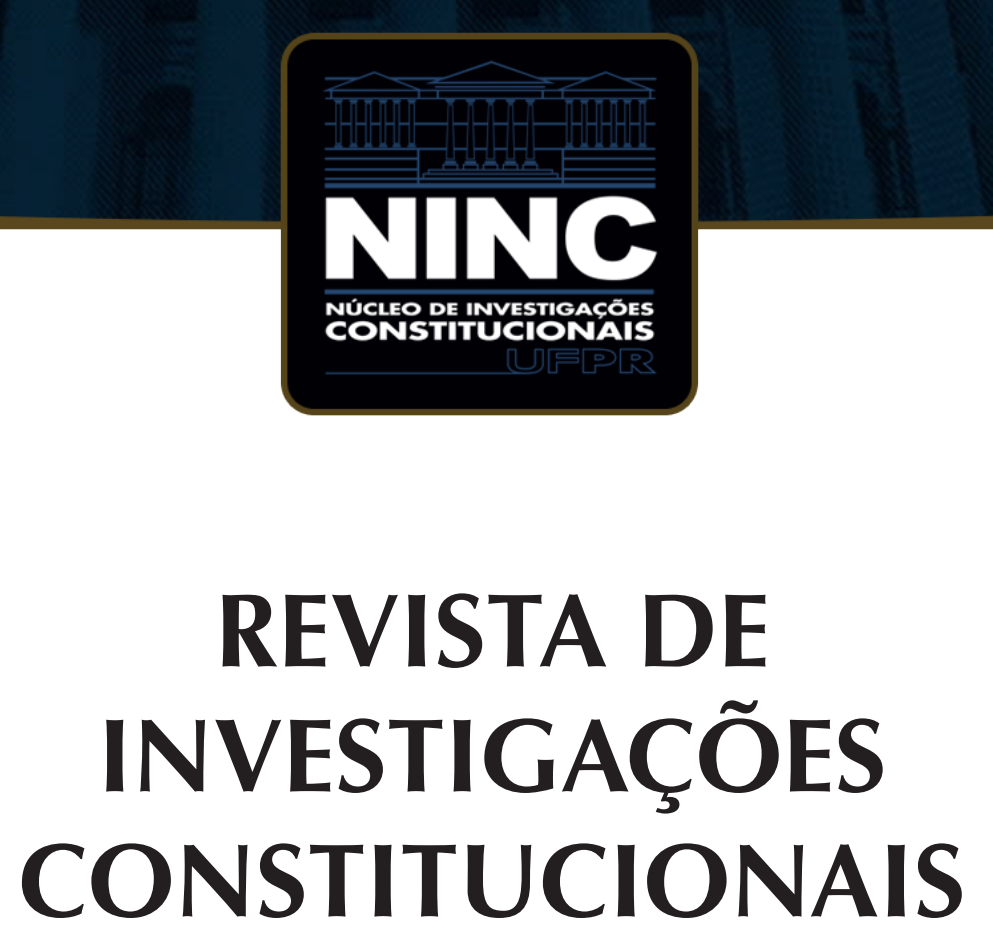

JOURNAL OF CONSTITUTIONAL RESEARCH

vol. 5 | n. 1 | janeiro/abril 2018 | ISSN 2359-5639 | Periodicidade quadrimestral Curitiba | Núcleo de Investigações Constitucionais da UFPR | www.ninc.com.br 


\title{
Is it time for a U.S. Article V Constitutional convention? A brief discussion about American constitutional reform procedure
}

\author{
É hora de uma convenção constitucional sobre o artigo V da \\ Constituição dos Estados Unidos? Uma breve discussão sobre o \\ procedimento norte-americano de reforma constitucional
}

\author{
KAREN DESOTO* \\ Rutgers University (United States of America) \\ kdesoto@earthlink.net
}

Recebido/Received: 20.09.2017 / September 20th, 2017

Aprovado/Approved: 27.10.2017 / October 27th, 2017

\begin{abstract}
This article discusses how the United States Constitution Article V Convention can be utilized to amend the constitution. Considering the intense political climate and frequent stagnation in Congress, the Article $V$ convention is an avenue for the fifty U.S. states to spur legislative action without the cooperation of the U.S. Congress. This paper explores whether an Article V Constitutional Convention could be utilized to start the process to identify and unify critical legislative initiatives amidst the current political climate. Part II explains the function, process, and historical usage of Article V. Part III discusses case law developments interpreting Article V. Part IV examines individual state constitutional conventions and their efficacy. Part V discuss the arguments for and against an Article V Constitutional Convention.
\end{abstract}

Keywords: constitutional convention; article V; constitutional reform procedure; constitutional amendment; United States.

\section{Resumo}

Este artigo discute como a Convenção do Artigo V da Constituição dos Estados Unidos pode ser utilizada para emendar a Constituição. Considerando o clima político intenso e a frequente estagnação no Congresso, a Convenção do Artigo $V$ é um caminho para os cinquenta Estados dos EUA estimularem ações legislativas sem a colaboração do Congresso. Este artigo explora se uma Convenção Constitucional do Artigo V poderia ser utilizada para iniciar o processo para identificar e unificar iniciativas legislativas críticas em meio ao atual clima político. A Parte Il explica a função, o processo e o uso histórico do Artigo V. A Parte III discute os desenvolvimentos da jurisprudência que interpretam o Artigo V. A Parte IV examina individualmente convenções constitucionais estaduais e sua eficácia. A Parte $V$ discute os argumentos a favor e contra a Convenção Constitucional do Artigo V.

Palavras-chave: convenção constitucional; artigo V; procedimento de reforma constitucional; emenda constitucional; Estados Unidos.

Como citar esse artigo/How to cite this article: DESOTO, Karen. Is it time for a U.S. Article V Constitutional convention? A brief discussion about American constitutional reform procedure. Revista de Investigações Constitucionais, Curitiba, vol. 5, n. 1, p. 249-260, jan./abr. 2018. DOI: 10.5380/rinc.v5i1.55332.

* Adjunct Professor at Rutgers University (United States of America). Juris Doctorate and Master of Laws at Temple University School of Law. Attorney at law and legal analyst. E-mail: kdesoto@earthlink.net. 


\section{CONTENTS}

1. Introduction; 2. What Is the Article V Constitutional Convention?; 3. Case Law on Article V; 4. State Constitutional Conventions; 5. Support and Opposition for Constitutional Convention; 6. Conclusion; 7. References.

\section{INTRODUCTION}

The United States Constitution Article V Convention is an untapped pathway to amend the constitution that has yet to be deployed. ${ }^{1}$ Considering the intense political climate and frequent stagnation in Congress, the Article $V$ convention may be a vehicle for the fifty U.S. states to spur legislative action without the cooperation of the U.S. Congress. ${ }^{2}$ However, an Article V Convention still relies on the participation of individual states, which may be a daunting task considering the polarization of American politics. ${ }^{3}$

This paper explores whether an Article V Constitutional Convention could be utilized to start the process to identify and unify critical legislative initiatives amidst the current political climate. Part II explains the function, process, and historical usage of Article V. ${ }^{4}$ Part III discusses case law developments interpreting Article V. ${ }^{5}$ Part IV examines individual state constitutional conventions and their efficacy. ${ }^{6}$ Part $V$ discuss the arguments for and against an Article V Constitutional Convention. ${ }^{7}$

\section{WHAT IS THE ARTICLE V CONSTITUTIONAL CONVENTION?}

Article $V$ of the United States Constitution provides two avenues, each with two steps, to amend the Constitution. 8 Article V states that:

The Congress, whenever two thirds of both Houses shall deem it necessary, shall propose Amendments to this Constitution, or, on the Application of the Legislatures of two thirds of the several States, shall call a Convention for proposing Amendments, which, in either Case, shall be valid to all Intents and Purposes, as Part of this

\footnotetext{
1 NEALE, Thomas H. The Article V Convention for Proposing Constitutional Amendments: Historical Perspectives for Congress. Congressional Research Service, Oct 22, 2012. Available at: <https://fas.org/sgp/crs/misc/R42592.pdf>. Last visited Jun 29, 2017. p. 5.

2 NEALE, Thomas H. The Article V Convention for Proposing Constitutional Amendments: Historical Perspectives for Congress. Congressional Research Service, Oct 22, 2012. Available at: <https://fas.org/sgp/crs/misc/R42592.pdf>. Last visited Jun 29, 2017. p. 5.

3 NEALE, Thomas H. The Article V Convention for Proposing Constitutional Amendments: Historical Perspectives for Congress Congressional Research Service, Oct 22, 2012. Available at: <https://fas.org/sgp/crs/misc/R42592.pdf>. Last visited Jun 29, 2017. p. 6.

4 For further discussion of Article V, see infra notes 8 - 37 and accompanying text.

5 For further discussion of case law on Article V, see infra notes 38 - 44 and accompanying text.

6 For further discussion of state constitutional conventions, see infra notes $45-58$ and accompanying text

7 For further discussion of the argument surrounding Article V, see infra notes 59 - 77 and accompanying text.

8 See supra notes $9-17$ and accompanying text.
} 
Constitution, when ratified by the Legislatures of three fourths of the several States, or by Conventions in three fourths thereof, as the one or the other Mode of Ratification may be proposed by the Congress; Provided that no Amendment which may be made prior to the Year One thousand eight hundred and eight shall in any Manner affect the first and fourth Clauses in the Ninth Section of the first Article; and that no State, without its Consent, shall be deprived of its equal Suffrage in the Senate. ${ }^{9}$

By way of the first avenue, Congress can propose an amendment by a vote of two-thirds of the Senate and of the House of Representatives.10 The amendment is then sent to the states to determine whether to ratify the amendment. ${ }^{11}$ If three-fourths of the states ratify the amendment, it is added to the Constitution. ${ }^{12}$ Thirty-three amendments have been proposed through this method, and twenty-seven have been ratified and added to the Constitution. ${ }^{13}$ Aside from the Twenty-Seventh Amendment, no amendments have been added to the Constitution since 1971.14

The states can circumnavigate Congress through the second avenue if twothirds of state legislatures request Congress to call an Article V Constitutional convention to propose Constitutional amendments. ${ }^{15}$ If such a request is successfully made, the states must set the agenda for the convention and Congress must hold a convention limited to that agenda. ${ }^{16}$ Proposed amendments are then sent to the states for the same ratification process as if they were submitted by Congress. ${ }^{17}$

The Framers' intent behind Article $V$ appears to have been to balance out the power of the federal government and allow the states to collectively act if Congress did not. ${ }^{18}$ Further, the Article $V$ convention was intended to give more direct power to the people through their state legislatures. ${ }^{19}$ The Article $V$ convention option was

\footnotetext{
9 U.S. Const. art. V.

10 U.S. Const. art. V.

11 U.S. Const. art. V.

12 EDITORS OF THE TENNESSEE LAW REVIEW. Article V Constitutional Conventions: A Primer. Tennessee Law Review, vol. 78, n. 3, p. 663-692, mar./may 2011. p. 664.

13 RAPPAPORT, Michael B.; STRAUSS, David A. Common Interpretation: Article V. National Constitution Center. Available at: $<$ https://constitutioncenter.org/interactive-constitution/articles/article-v/article-v-by-michael-b-rappaport-and-david-a-strauss/interp/22>. Last visited Jun 29, 2017.

14 RAPPAPORT, Michael B.; STRAUSS, David A. Common Interpretation: Article V. National Constitution Center. Available at: $<$ https://constitutioncenter.org/interactive-constitution/articles/article-v/article-v-by-michael-b-rappaport-and-david-a-strauss/interp/22>. Last visited Jun 29, 2017.

15 EDITORS OF THE TENNESSEE LAW REVIEW. Article V Constitutional Conventions: A Primer. Tennessee Law Review, vol. 78, n. 3, p. 663-692, mar./may 2011. p. 664.

16 PULIGNANO, Vincent. A Known Unknown: The Call for an Article V Convention. Florida Law Review, vol. 67, p. 151-160, 2016. p. 152.

17 EDITORS OF THE TENNESSEE LAW REVIEW. Article V Constitutional Conventions: A Primer. Tennessee Law Review, vol. 78, n. 3, p. 663-692, mar./may 2011. p. 664.

18 NEALE, Thomas H. The Article V Convention for Proposing Constitutional Amendments: Historical Perspectives for Congress. Congressional Research Service, Oct 22, 2012. Available at: <https://fas.org/sgp/crs/misc/R42592.pdf $>$. Last visited Jun 29, 2017. p. 11.

19 PULIGNANO, Vincent. A Known Unknown: The Call for an Article V Convention. Florida Law Review, vol. 67, p. 151-160,
} 
added after George Mason commented that Congress would be unlikely to propose an amendment that would limit its own power, thus Article $V$ was aimed to curtail Congress's power and provide more direct power to individual citizens through their state constitutional convention representatives. ${ }^{20}$

Furthermore, the Framers intended that it would not be excessively difficult to call an Article V convention.21 Under the Articles of Confederation, every state needed to ratify proposed amendments, thus Article $V$ aimed to make it easier for the people to change the Constitution. 22

The Article V convention circumnavigates Congress and empowers people with the ability to amend the constitution, because "[a]lthough a convention is summoned by the Legislature, it derives its power from the sovereign people."23 James Madison remarked in The Federalist Papers that "a constitutional road to the decision of the people, ought to be marked out, and kept open, for certain great and extraordinary occasions." 24

The Article $V$ convention has not been effectively utilized to date. 25743 requests for Article $V$ conventions have been made over time, most of which occurred in the 1900s. ${ }^{26}$ Every state has petitioned for an Article $V$ convention at some point. ${ }^{27}$ Three notable examples are the campaigns for the direct election of senators by states, reapportionment of state legislatures, and a balanced budget requirement.28 The direct election effort failed around the turn of the $20^{\text {th }}$ century, but ultimately led to the

\footnotetext{
2016. p. 151.

20 ROGERS, James Kenneth. The Other Way to Amend the Constitution: The Article V Constitutional Convention Amendment Process. Harvard Journal of Law \& Public Policy, Cambridge, vol. 30, p. 1005-1022, 2007. p. 1007.

21 HANSON, Walker. The States' Power to Effectuate Constitutional Change: Is Congress Currently Required to Convene a National Convention for the Proposing of Amendments to the United States Constitution. Geo. J. L. \& Pub. Pol'y, vol. 9, n. 1, p. 245-? 2011. p. 249-249.

22 HANSON, Walker. The States' Power to Effectuate Constitutional Change: Is Congress Currently Required to Convene a National Convention for the Proposing of Amendments to the United States Constitution. Geo. J. L. \& Pub. Pol'y, vol. 9, n. 1, p. 245-? 2011. p. 248-249.

23 In re Opinion of the Justices, 132 Me. 491, 167 A. 176, 179 (1933)

24 MADISON, James. No. 49. In: HAMILTON, Alexander; MADISON, James; JAY, John. The Federalist Papers. Oxford: Oxford University Press, 2008.

25 NEALE, Thomas H. The Article V Convention for Proposing Constitutional Amendments: Historical Perspectives for Congress. Congressional Research Service, Oct 22, 2012. Available at: <https://fas.org/sgp/crs/misc/R42592.pdf >. Last visited Jun 29, 2017.

$26 \mathrm{NEALE}$, Thomas $\mathrm{H}$. The Article V Convention for Proposing Constitutional Amendments: Historical Perspectives for Congress. Congressional Research Service, Oct 22, 2012. Available at: $<$ https://fas.org/sgp/crs/misc/R42592.pdf $>$. Last visited Jun 29, 2017. p. 9.

27 PENROSE, Mary Margaret. Conventional Wisdom: Acknowledging Uncertainty in the Unknown. Tennessee Law Review, vol. 78, p. 789-805, 2011. p. 793.

28 NEALE, Thomas $\mathrm{H}$. The Article V Convention for Proposing Constitutional Amendments: Historical Perspectives for Congress. Congressional Research Service, Oct 22, 2012. Available at: $<$ https://fas.org/sgp/crs/misc/R42592.pdf $>$. Last visited Jun 29, 2017. p. 12-13.
} 
Seventeenth Amendment, therefore providing a good example of the "prodding effect," where the effort from states is sufficient to prod Congress to act in a given area. 29

The apportionment initiative gained the support of thirty-three states in the 1950s; however, some states withdrew their applications over time. ${ }^{30}$ An initiative for a federal budget amendment came close to an Article $V$ convention with the support of thirty-two of the requisite thirty-eight states. 31 Similarly to the direct election campaign, the federal budget initiative prodded Congress to enact the Gramm-Rudman -Hollings Balanced Budget and Emergency Deficit Control Act of 1985, which required a balanced budget by $1993 .{ }^{32}$ After the budget amendment effort, Article V convention interest waned until recent years. 33

Efforts for a balanced budget amendment continue, with twenty seven state applications as of 2015.34 In 2010, the Tea Party gained traction surrounding the Repeal Amendment, which would allow for the repeal of any federal law if the legislatures of two-thirds of the states agreed. The Repeal Amendment gained the support of twelve states. ${ }^{35}$ According to a Harris Interactive survey in 2005, more than sixty-five percent of the population supports seven theoretical amendments where Congress has not acted. ${ }^{36}$ As of 2011 , thirty-three states were applying for a general Article V constitutional convention. 37

\footnotetext{
29 NEALE, Thomas H. The Article V Convention for Proposing Constitutional Amendments: Historical Perspectives for Congress. Congressional Research Service, Oct 22, 2012. Available at: <https://fas.org/sgp/crs/misc/R42592.pdf $>$. Last visited Jun 29, 2017. p. 14.

30 EDITORS OF THE TENNESSEE LAW REVIEW. Article V Constitutional Conventions: A Primer. Tennessee Law Review, vol. 78, n. 3, p. 663-692, mar./may 2011. p. 666.

31 NEALE, Thomas H. The Article V Convention for Proposing Constitutional Amendments: Historical Perspectives for Congress. Congressional Research Service, Oct 22, 2012. Available at: <https://fas.org/sgp/crs/misc/R42592.pdf >. Last visited Jun 29, 2017.

32 EDITORS OF THE TENNESSEE LAW REVIEW. Article V Constitutional Conventions: A Primer. Tennessee Law Review, vol. 78, n. 3, p. 663-692, mar./may 2011. p. 666.

33 NEALE, Thomas H. The Article V Convention for Proposing Constitutional Amendments: Historical Perspectives for Congress. Congressional Research Service, Oct 22, 2012. Available at: <https://fas.org/sgp/crs/misc/R42592.pdf >. Last visited Jun 29, 2017. p. 5.

34 Doing the math for a new Constitutional Convention - National Constitution Center, National Constitution Center - constitutioncenter.org (2015), https://constitutioncenter.org/blog/doing-the-math-for-a-new-constitutional-convention (last visited Jul 17, 2017).

35 ZERNIKE, Kate. Proposed Amendment Would Enable States to Repeal Federal Law. The New York Times, New York, Dec 20, 2010. Available at: <http://www.nytimes.com/2010/12/20/us/politics/20states.html>. Last visited Jul 2, 2017.

36 ROGERS, James Kenneth. The Other Way to Amend the Constitution: The Article V Constitutional Convention Amendment Process. Harvard Journal of Law \& Public Policy, Cambridge, vol. 30, p. 1005-1022, 2007. p. 1007.

37 PAULSEN, Michael Stokes. How to Count to Thirty-Four: the Constitutional Case for a Constitutional Convention. Harv. J.L. \& Pub. Pol'y, Cambridge, vol. 34, p. 837-?, 2011. p. 857.
} 


\section{CASE LAW ON ARTICLE V}

Amendments to the Constitution are primarily a legislative function. ${ }^{38}$ The president has no official role in the Article $\mathrm{V}$ amendment process. ${ }^{39}$ In Hollingsworth $v$. Virginia, the Supreme Court held that constitutional amendments should not be presented to the president for signature and the president has no veto power over a constitutional amendment because of the lack of role set out in Article V.40

The Constitution does not set any deadlines for ratification of proposed amendments. ${ }^{41}$ In Dillon v. Gloss, the Supreme Court held that Congress has the power to impose a deadline for ratification, stating that:

We do not find anything in the article which suggests that an amendment, once proposed, is to be open to ratification for all time, or that ratification in some of the states may be separated from that in others by many years and yet be effective. We do find that which strongly suggests the contrary. First, proposal and ratification are not treated as unrelated acts, but as succeeding steps in a single endeavor, the natural inference being that they are not to be widely separated in time. Secondly, it is only when there is deemed to be a necessity therefore that amendments are to be proposed, the reasonable implication being that, when proposed, they are to be considered and disposed of presently. Thirdly, as ratification is but the expression of the approbation of the people, and is to be effective when had in three-fourths of the states, there is a fair implication that it must be sufficiently contemporaneous in that number of states to reflect the will of the people in all sections at relatively the same period, which, of course, ratification scattered through a long series of years would not do.42

Congress has since imposed a seven-year deadline for ratification of amendments. ${ }^{43}$ This can prove challenging for an Article $V$ convention because of the timeconsuming process of organizing movements and state legislatures in coordination with other states. 44

\footnotetext{
38 Wilson v. Guggenheim, 70 F. Supp. 417, 419 (E.D.S.C. 1947).

39 Hollingsworth v. State of Virginia, 3 U.S. 378,379 (1798).

40 Hollingsworth v. State of Virginia, 3 U.S. 378, 379 (1798).

41 U.S. Const. art. V

42 Dillon v. Gloss, 256 U.S. 368, 374-75 (1921).

43 RAPPAPORT, Michael B.; STRAUSS, David A. Common Interpretation: Article V. National Constitution Center. Available at: $<$ https://constitutioncenter.org/interactive-constitution/articles/article-v/article-v-by-michael-b-rappaport-and-david-a-strauss/interp/22>. Last visited Jun 29, 2017.

44 NEALE, Thomas H. The Article V Convention for Proposing Constitutional Amendments: Historical Perspectives for Congress. Congressional Research Service, Oct 22, 2012. Available at: <https://fas.org/sgp/crs/misc/R42592.pdf $>$. Last visited Jun 29, 2017. p. 5.
} 


\section{STATE CONSTITUTIONAL CONVENTIONS}

State constitutional conventions can provide a model for the way a potential Article $\mathrm{V}$ convention should or could function. ${ }^{45}$ Every state has amended its constitution, and the states collectively have amended their constitutions 7,481 times. 46 All of the states allow their state legislatures to call constitutional conventions, and fourteen states provide for the people to periodically decide by referendum whether to call a constitutional convention. ${ }^{47}$ For instance, Florida holds a commission every twenty years to determine whether to amend their constitution. ${ }^{48}$ Fifteen states have held constitutional conventions since 1965.49

Additionally, New York will have a referendum on the ballot this November to determine whether to hold a constitutional convention.50 This option is available to New Yorkers every twenty years; however, it has not been exercised for the past eighty years. 51 Many believe that voters will decide to call for a convention this year based on motivations surrounding the current President and federal administration. 52 Groups campaigning for a constitutional convention champion causes such as campaign finance reform, redistricting, term limits, marijuana legalization, the judiciary structure, and home rule for counties and municipalities. 53

The process for a New York constitutional convention commences when a majority of voters elect to do so. ${ }^{54}$ As a result, electors from every senate district elect three delegates to send to the convention, and electors voting at the same election elect fifteen delegates-at-large. 55 Elected delegates would convene for the convention

45 DINAN, Josh. State Constitutional Amendments and American Constitutionalism. Okla. City U. L. Rev., vol. 41, n. 1, p. 27-52, mar./may 2016.

46 DINAN, Josh. State Constitutional Amendments and American Constitutionalism. Okla. City U. L. Rev., vol. 41, n. 1, p. 27-52, mar./may 2016. p. 30.

47 DINAN, Josh. State Constitutional Amendments and American Constitutionalism. Okla. City U. L. Rev., vol. 41, n. 1, p. 27-52, mar./may 2016. p. 32-33.

48 DINAN, Josh. State Constitutional Amendments and American Constitutionalism. Okla. City U. L. Rev., vol. 41, n. 1, p. 27-52, mar./may 2016. p. 34.

49 Other State Solutions for Convention | Citizens' Committee for an Effective Constitution, Nyconstitution.org. Available at: $<$ http://nyconstitution.org/other-states/convention/1965-15-states-have-held-constitutional-conventions >. Last visited Jul $16,2017$.

50 FODERARO, Lisa W. A Constitutional Convention for New York? This May Be the Year. The New York Times, New York, Jul 5 , 2017. Available at: <https://www.nytimes.com/2017/07/05/nyregion/constitutional-convention-voting-new-york.html>.

51 FODERARO, Lisa W. A Constitutional Convention for New York? This May Be the Year. The New York Times, New York, Jul 5 , 2017. Available at: <https://www.nytimes.com/2017/07/05/nyregion/constitutional-convention-voting-new-york.html>.

52 FODERARO, Lisa W. A Constitutional Convention for New York? This May Be the Year. The New York Times, New York, Jul 5, 2017. Available at: <https://www.nytimes.com/2017/07/05/nyregion/constitutional-convention-voting-new-york.html>.

53 FODERARO, Lisa W. A Constitutional Convention for New York? This May Be the Year. The New York Times, New York, Jul 5 , 2017. Available at: <https://www.nytimes.com/2017/07/05/nyregion/constitutional-convention-voting-new-york.html>.

54 See infra notes $9-17$ and accompanying text.

55 Article XIX, Section 2, New York Constitution 
in April 2018.56 The convention has the power to appoint officers and set the rules of proceedings. 57 Amendments are approved by a majority of delegates, and approved amendments are submitted to a vote of electors six weeks after the convention. ${ }^{58}$

\section{SUPPORT AND OPPOSITION FOR CONSTITUTIONAL CONVEN- TION}

Momentum has been building surrounding recent attempts to call an Article V convention. Current dissolution and polarization of U.S. citizens has emerged due to the political climate. ${ }^{59}$ Consequently, the intended use of Article $V$ at this time would correspond with the Framers' intent of giving more direct power to the people.60 Individuals' trust and confidence in the government has reached a low point, and as of 2016, only 42 percent of citizens trust the country's political leaders. 61

The 2016 presidential election was composed of poorly rated candidates, and many attribute Donald Trump's success in the election to voter dissatisfaction with the government and politicians.62 Trump's presidency is extraordinary, given the factor that not since the 1928 election of Herbert Hoover has the U.S. had a president that did not have either a political or military background.63 Moreover, Americans trust in Washington is at historical lows, with more than eighty percent of the population believing there is little to no trust that the government in D.C. is capable of doing what is right.64

Considering the election results, an Article $\mathrm{V}$ convention could be a means of restoring federalism where the President and Congress do not impose constitutional limits.65 Additionally, polarization between political parties is growing over time,

\footnotetext{
56 Article XIX, Section 2, New York Constitution

57 Article XIX, Section 2, New York Constitution

58 Article XIX, Section 2, New York Constitution

59 DOHERTY, Carroll. 7 things to know about polarization in America Pew Research Center. Pew Research, Jun 12, 2014. Available at: <http://www.pewresearch.org/fact-tank/2014/06/12/7-things-to-know-about-polarization-in-america>. Last visited Jul $18,2017$.

60 See infra notes $16-18$ and accompanying text.

61 GALLUP.COM. "Americans' Trust in Political Leaders, Public at New Lows". Available at: <http://www.gallup.com/ poll/195716/americans-trust-political-leaders-public-new-lows.aspx>. Last visited Jul 17, 2017.

62 GALLUP.COM. "Americans' Trust in Political Leaders, Public at New Lows". Available at: <http://www.gallup.com/ poll/195716/americans-trust-political-leaders-public-new-lows.aspx>. Last visited Jul 17, 2017.

63 SOUSA, Gregory. U.S. Presidents With The Least Prior Political Experience. World Atlas, 2016. Available at: <http://www.worldatlas.com/articles/u-s-presidents-with-the-least-prior-political-experience.html>. Last visited Jul 31, 2017.

64 GALLUP.COM "Trust in Government". Available at: <http://www.gallup.com/poll/5392/trust-government.aspx>. Last visited Jul 31, 2017.

65 NATELSON, Robert G. The Article V Convention Process and the Restoration of Federalism. Harv. J.L. \& Pub. Pol'y, Cambridge, vol. 36, n. 3, p. 955-960, 2016.
} 
resulting in deadlocks in government.66 President Obama began to use executive orders to implement policy amidst Congress's failure to act. 67

The wide use and popularity of the internet and social media also make now the opportune time for an Article V Convention because initiatives for amendments can be organized and executed much broader and faster than the prior attempts in the 1960s-1980s.68

However, many arguments against an Article V Constitution exist.69 For instance, many scholars agree that the risk of a runaway convention is the most notable problem with a potential Article V constitutional convention. ${ }^{70}$ The possibility of a "runaway convention," or a convention where adverse amendments are adopted, is also cited as a primary concern with an Article $V$ convention. ${ }^{71}$

Similarly, some argue that an Article $V$ convention could result in replacing the entire constitution. ${ }^{72}$ However, this risk is curtailed several ways. ${ }^{73}$ First, an Article V convention can be limited by issue. ${ }^{74}$ Second, the ratification process provides a safety net in case delegates propose undesirable amendments. ${ }^{75}$

The brief text of Article $V$ leaves several questions open, such as how convention members are chosen, how convention rules are adopted, and Congress's power to create an alternative ratification procedure. ${ }^{76}$ Nevertheless, the Supreme Court has provided some clarity on the process, and Congress can make further rules as necessary. ${ }^{77}$

\footnotetext{
66 DOHERTY, Carroll. 7 things to know about polarization in America Pew Research Center. Pew Research, Jun 12, 2014. Available at: <http://www.pewresearch.org/fact-tank/2014/06/12/7-things-to-know-about-polarization-in-america>. Last visited Jul $18,2017$.

67 COHEN, Tom. Obama uses executive orders as a political tool. CNN, Nov 01, 2011. Available at: <http://www.cnn. com/2011/11/01/politics/obama-executive-orders/index.html>. Last visited Aug 1, 2017.

68 NEALE, Thomas H. The Article V Convention for Proposing Constitutional Amendments: Historical Perspectives for Congress. Congressional Research Service, Oct 22, 2012. Available at: <https://fas.org/sgp/crs/misc/R42592.pdf $>$. Last visited Jun 29, 2017. p. 5.

69 PULIGNANO, Vincent. A Known Unknown: The Call for an Article V Convention. Florida Law Review, vol. 67, p. 151-160, 2016. p. 158.

70 PULIGNANO, Vincent. A Known Unknown: The Call for an Article V Convention. Florida Law Review, vol. 67, p. 151-160, 2016. p. 158.

71 PULIGNANO, Vincent. A Known Unknown: The Call for an Article V Convention. Florida Law Review, vol. 67, p. 151-160, 2016. p. 158.

72 PULIGNANO, Vincent. A Known Unknown: The Call for an Article V Convention. Florida Law Review, vol. 67, p. 151-160, 2016. p. 158

73 See supra notes $74-75$ and accompanying text.

74 ABBOTT, Greg. The Myths and Realities of Article V. Tex. Rev. L. \& Pol., vol. 21, n. 1, p. 1-61, sept./nov. 2016. p. $31-32$.

75 ABBOTT, Greg. The Myths and Realities of Article V. Tex. Rev. L. \& Pol., vol. 21, n. 1, p. 1-61, sept./nov. 2016. p. 56.

76 COLON-RIOS, Joel; HUTCHINSON, Allan C. Democracy and Revolution: An Enduring Relationship? Denver Law Review, vol. 89, n. 3, 593-610, 2012. p. 603.

77 WALKER, Bill. The Article V Convention: Discussing the Reality Versus the Fantasy. 28 Thomas M. Cooley L. Rev., vol. 28, n. 1, p. 21-36, 2011. p. 27.
} 


\section{CONCLUSION}

In conclusion, the political climate, polarization of political parties, discontentment of the 2016 Presidential election and widespread distrust of government warrants use of the Article $V$ convention as intended by the Constitutional framers. 78 The question remains: has history brought the United States to an "extraordinary occasion" as envisioned by James Madison and the other framers to finally implement an Article V Constitutional convention?79 An Article V convention may be the path to quell the political discord and congressional inaction and empower U.S. citizens and states to circumnavigate Congress or at the very least "prod" it into legislative action. 80 However, as awe-inspiring as the idea may be to actually curtail Congress's power and provide citizens and individuals with some control of the legislative agenda, the prodigious task of a Constitutional convention requires the active participation of individual states and citizens, given the division in American politics, such a task may be possible but formidable. 81

\section{REFERENCES}

ABBOTT, Greg. The Myths and Realities of Article V. Tex. Rev. L. \& Pol., vol. 21, n. 1, p. 1-61, sept./ nov. 2016.

COHEN, Tom. Obama uses executive orders as a political tool. CNN, Nov 01, 2011. Available at: <http://www.cnn.com/2011/11/01/politics/obama-executive-orders/index.html>. Last visited Aug 1, 2017.

COLON-RIOS, Joel; HUTCHINSON, Allan C. Democracy and Revolution: An Enduring Relationship? Denver Law Review, vol. 89, n. 3, 593-610, 2012.

DINAN, Josh. State Constitutional Amendments and American Constitutionalism. Okla. City U. L. Rev., vol. 41, n. 1, p. 27-52, mar./may 2016.

DOHERTY, Carroll. 7 things to know about polarization in America Pew Research Center. Pew Research, Jun 12, 2014. Available at: <http://www.pewresearch.org/fact-tank/2014/06/12/7-thingsto-know-about-polarization-in-america>. Last visited Jul 18, 2017.

EDITORS OF THE TENNESSEE LAW REVIEW. Article V Constitutional Conventions: A Primer. Tennessee Law Review, vol. 78, n. 3, p. 663-692, mar./may 2011.

\footnotetext{
78 See infra notes 59-68 and accompanying text.

79 See infra note 21 and accompanying text.

80 NEALE, Thomas H. The Article V Convention for Proposing Constitutional Amendments: Historical Perspectives for Congress. Congressional Research Service, Oct 22, 2012. Available at: <https://fas.org/sgp/crs/misc/R42592.pdf >. Last visited Jun 29, 2017. p. 14.

81 See infra note 18 and accompanying text.
} 
FODERARO, Lisa W. A Constitutional Convention for New York? This May Be the Year. The New York Times, New York, Jul 5, 2017. Available at: <https://www.nytimes.com/2017/07/05/nyregion/constitutional-convention-voting-new-york.html>.

GALLUP.COM "Trust in Government". Available at: <http://www.gallup.com/poll/5392/trust-government.aspx>. Last visited Jul 31, 2017.

GALLUP.COM. "Americans' Trust in Political Leaders, Public at New Lows". Available at: <http:// www.gallup.com/poll/195716/americans-trust-political-leaders-public-new-lows.aspx>. Last visited Jul 17, 2017.

HANSON, Walker. The States' Power to Effectuate Constitutional Change: Is Congress Currently Required to Convene a National Convention for the Proposing of Amendments to the United States Constitution. Geo. J. L. \& Pub. Pol'y, vol. 9, n. 1, p. 245-?, 2011.

MADISON, James. No. 49. In: HAMILTON, Alexander; MADISON, James; JAY, John. The Federalist Papers. Oxford: Oxford University Press, 2008.

NATELSON, Robert G. The Article V Convention Process and the Restoration of Federalism. Harv. J.L. \& Pub. Pol'y, Cambridge, vol. 36, n. 3, p. 955-960, 2016.

NEALE, Thomas H. The Article V Convention for Proposing Constitutional Amendments: Historical Perspectives for Congress. Congressional Research Service, Oct 22, 2012. Available at: <https:// fas.org/sgp/crs/misc/R42592.pdf>. Last visited Jun 29, 2017.

PAULSEN, Michael Stokes. How to Count to Thirty-Four: the Constitutional Case for a Constitutional Convention. Harv. J.L. \& Pub. Pol'y, Cambridge, vol. 34, p. 837-?, 2011.

PENROSE, Mary Margaret. Conventional Wisdom: Acknowledging Uncertainty in the Unknown. Tennessee Law Review, vol. 78, p. 789-805, 2011.

PULIGNANO, Vincent. A Known Unknown: The Call for an Article V Convention. Florida Law Review, vol. 67, p. 151-160, 2016.

RAPPAPORT, Michael B.; STRAUSS, David A. Common Interpretation: Article V. National Constitution Center. Available at: $<$ https://constitutioncenter.org/interactive-constitution/articles/article-v/article-v-by-michael-b-rappaport-and-david-a-strauss/interp/22>. Last visited Jun 29, 2017. ROGERS, James Kenneth. The Other Way to Amend the Constitution: The Article V Constitutional Convention Amendment Process. Harvard Journal of Law \& Public Policy, Cambridge, vol. 30, p. 1005-1022, 2007.

SOUSA, Gregory. U.S. Presidents With The Least Prior Political Experience. World Atlas, 2016. Available at: <http://www.worldatlas.com/articles/u-s-presidents-with-the-least-prior-political-experience.html>. Last visited Jul 31, 2017.

WALKER, Bill. The Article V Convention: Discussing the Reality Versus the Fantasy. 28 Thomas $\mathbf{M}$. Cooley L. Rev., vol. 28, n. 1, p. 21-36, 2011. 
ZERNIKE, Kate. Proposed Amendment Would Enable States to Repeal Federal Law. The New York Times, New York, Dec 20, 2010. Available at: <http://www.nytimes.com/2010/12/20/us/politics/20states.html>. Last visited Jul 2, 2017. 